Aquacultural Engineering

Volume 8, Issue 4, 1989, Pages 223-239

\title{
Changes in protein, carbohydrates and gross energy in the marine microalga Dunaliella tertiolecta (Butcher) by nitrogen concentrations as nitrate, nitrite and urea
}

Jaime Fábregas, Julio Abalde, Buenaventura Cabezas \& Concepción Herrero

Departamento de Microbiología y Parasitología, Facultad de Farmacia, Universidad de Santiago, Spain

Fabregas J, Abalde J, Cabezas B, Herrero C. Changes in protein, carbohydrates and gross energy in the marine microalga dunaliella tertiolecta (butcher) by nitrogen concentrations as nitrate, nitrite and urea. Aquac Eng 1989;8(4):223-39.

ISSN: 01448609

DOI: 10.1016/0144-8609(89)90011-3 http://dx.doi.org/10.1016/0144-8609(89)90011-3

\section{Abstract}

Cultures of the marine microalga Dunaliella tertiolecta were grown in nitrate, nitrite and urea at concentrations ranging from 0.25 to $16 \mathrm{mg}$ atom. $\mathrm{N} /$ litre.

Great biochemical variability has been shown in this microalga as a function of high nitrogen concentrations for all the sources used. Cellular protein and carbohydrates and gross energy per $\mathrm{ml}$ of culture increased proportionally to the increase in the $\mathrm{N}$ concentration, under conditions that maintain constant the $\mathrm{N} P$ ratio. Two kinds of cultures are defined: low nitrogen cultures $<2 \mathrm{mg}$ atom. $\mathrm{N} /$ litre, and high nitrogen cultures $>2 \mathrm{mg}$ atom. $\mathrm{N} /$ litre. Variability mainly appears in the second type of cultures.

Protein/cell values of up to $4.94,5.47$ and 1.41 times higher have been observed in nitrate, nitrite and urea cultures, respectively, when comparing protein/cell values obtained in high $\mathrm{N}$ cultures with those obtained in low $\mathrm{N}$ cultures. Similar variations have been observed in the carbohydrates/cell content, with values up to $3 \cdot 16,3.30$ and 1.77 times higher in the high than in the low $\mathrm{N}$ cultures. 
Biochemical variability is greater in nitrate and nitrite cultures (inorganic sources of nitrogen) than in urea cultures (organic source of $\mathrm{N}$ ).

Lipid/carbohydrates ratio seems to be a convenient parameter for characterizing the physiological state of a microalgal population.

This biochemical variability must have a marked effect on the value of this microalga as a source of single cell protein, chemicals or as feed in mariculture.

\section{Indexed keywords}

Algae; Cell Culture--Growth Kinetics

Biochemical Variability; Dunaliella Tertiolecta; Marine Microalga Cultures; Single Cell Protein

Marine Biology

Algae; Dunaliella; Dunaliella tertiolecta

\section{INTRODUCTION}

Dunaliella tertiolecta (Butcher) is a biflagellate unicellular green alga with a cell structure typical of the members of the order Volvocales (class Chlorophyceae), though lacking a cell wall (Oliveira et al., 1980). It is normally found in marine habitats, where it can survive in a wide range of salinities (Ben-Amotz \& Avron, 1978; Fabregas et al. , 1986a).

Different conditions in nutrient availability produce changes in the microalgal biochemical conditions (Spoehr \& Milner, 1949). Nitrogen deficiency in the culture medium varies the chemical composition of microalgae (Hobson \& Pariser, 1971; Myklestad \& Haug, 1972). Great variabilities in protein, chlorophyll and RNA contents have been shown in cultures of different marine microalgae at high nutrient concentrations (Fabregas et al., 1985, 1986a).

Variations in protein and chlorophyll concentration have been found in batch cultures of D. tertiolecta at high nutrient concentrations (Fabregas et al., 1986 b) and, in the same way, growth of this marine microalga in mass cultures is also coupled to changes in nutrient concentration, and variations occur in protein, chlorophyll $a$, carbohydrates and RNA content, showing differences of 197, 255, 142 and 150\%, respectively (Fabregas et al., 1986a). Similarly, D. tertiolecta showed significant differences in carbohydrate and protein composition in different media (Wikfors et al., 1984) and production of 
protein, carbohydrates and lipids, as percentages of dry weight, was evaluated for selected concentrations of nitrate and phosphate (Wikfors, 1986).

Most microalgae can utilize nitrate, nitrite or urea as nitrogen sources. Not only the nitrogen concentration, but also the source of this element used in the culture medium can produce important changes in the growth and biochemical composition of microalgal cells.

In the present work we analyzed the growth and biochemical composition of the marine microalga Dunaliella tertiolecta cultured with different sources and concentrations of nitrogen, as nitrate, nitrite and urea, adjusting the phosphorus concentrations in order to maintain constant the N/P ratio.

Dunaliella tertiolecta is useful as high protein material, in the production of chemicals as glycerol and b-carotene (Ben-Amotz \& Avron, 1978, 1980; Evans et al., 1982), as a source of single cell protein (Fabregas \& Herrero, 1985), as a source of minerals in fish diets (Fabregas \& Herrero, 1986) besides its use in aquaculture for feeding Artemia, rotifers (Mason, 1963), in the rearing of marine fishes (Scott \& Baynes, 1979) and in rearing of bivalve molluscs (Walne, 1974; Wikfors et al. , 1984).

An improved knowledge of its growth, composition and chemical variability will lead to its better use and allow high algal yields to be obtained.

\section{MATERIALS AND METHODS}

The marine microalga D. tertiolecta was obtained from The Culture Centre of Algae and Protozoa, Cambridge, UK. Dunaliella tertiolecta was cultured with different sources and concentrations of nitrogen. It was cultured in sea-water filtered through a 0-45 $\mu \mathrm{m}$ Millipore filter, autoclaved at $120^{\circ} \mathrm{C}$ for 60 min and enriched with $\mathrm{ZnCl}_{2}, 1 \mu \mathrm{M} ; \mathrm{MnCl}_{2}, 1$ $\mu \mathrm{M} ; \mathrm{Na}_{2} \mathrm{MoO}_{4}, 1 \mu \mathrm{M}$; $\mathrm{CoCl}_{3}, 0.1 \mu \mathrm{M}$; $\mathrm{CuSO}_{4}, 0.1 \mu \mathrm{M}$; ferric citrate, $20 \mu \mathrm{M}$; thiamine, 35 $\mu \mathrm{g} /$ litre; biotin, $5 \mu \mathrm{g} /$ litre; $\mathrm{B}_{12}$, $3 \mu \mathrm{g} /$ litre; EDTA, 26.4 mM; Tris-HCl, $15 \mathrm{mM}$; $\mathrm{pH}$ 7.6. The nitrogen sources used were: nitrate as $\mathrm{NaNO}_{3}$, nitrite as $\mathrm{NaNO}_{2}$ and organic nitrogen as urea. The phosphorus concentrations, as $\mathrm{NaH}_{2} \mathrm{PO}_{4}$, were adjusted in order to maintain constant the N/P ratio.

We used seven initial concentrations of each nitrogen compound: 0.25, 0.50, 1, 2, 4, 8 and $16 \mathrm{mg}$ atom.N/litre and, respectively, phosphorus concentrations of $12 \cdot 5,25,50$, $100,200,400$ and $800 \mu \mathrm{g}$ atom.P/litre, in order to maintain constant the N/P ratio. All the remaining nutrients were maintained initially constant at the concentrations given 
above. The $7 \times 3$ resulting media are expressed in function of the nitrogen concentration but phosphorus concentration was proportionally changed.

Cultures were carried out in Kimax screw-capped test-tubes $(15 \mathrm{~cm} \times 2.5 \mathrm{~cm})$ with 45 $\mathrm{ml}$ of medium. All cultures were maintained in a controlled environmental incubator at $18 \pm 1^{\circ} \mathrm{C}, 35 \%$ o salinity and $3900 \mathrm{Ix}$ light from fluorescent lamps (Osram daylight L55/10). A 12:12 light-dark cycle was maintained. An inoculum of $5 \times 104$ logarithmic phase cells $/ \mathrm{ml}$ was used. All the experiments were carried out in duplicate. Cultures were unialgal.

Transmittance of the cultures was determined by using a Colemann II 6/20 spectrophotometer reading at $530 \mathrm{~nm}$ and values were expressed as (100 - T). Cellular density was determined by counting culture aliguots in a Thoma chamber. For knowing growth velocity we calculate doublings/day:

$$
\mathrm{dbls} / \mathrm{day}=\frac{\ln N(n)-\ln N(i)}{\ln 2(t n-t i)}
$$

where $t i$ and $t n$ are the initial and final time of the logarithmic phase, both expressed in days, and $N U$ ) and $N(n)$ are the initial and final cellular density, respectively.

Samples for biochemical determinations were always collected at the same time of the light period because biochemical composition of microalgal cells can vary depending on the moment in the light period at which the sample is taken (Ganf et al. , 1986).

Chlorophylls were extracted from the cells in acetone-methanol $2: 1$ at $4^{\circ} \mathrm{C}$ for $48 \mathrm{~h}$. The extracts were filtered through a Fluoropore Millipore filter for clarification (Fabregas et al., 1984), and absorbances of the pigment extract at specific wavelengths were recorded. The concentration of chlorophyll a was determined by the formula of Parsons and Strickland (1965).

Protein and carbohydrates were measured in the crude extract obtained after collecting the microalgal cells by centrifugation, resuspending them in distilled water and breaking them in an ultrasonic disintegrator. After sonication the extracts were centrifuged again, the pellets were discarded and protein and carbohydrates were measured in the supernatants. Protein was measured by the dye-binding method (Bradford, 1976) and carbohydrates by the phenol-sulphuric acid method as described by Kochert (1978a). 
Lipids were measured by the charring method of Marsh and Weinstein (1966). Ribonucleic acid (RNA) was extracted with perchloric acid and determined as described by Kochert (1978b).

Gross energy of the microalgal cells under the different conditions was calculated at the stationary phase using the formula of the National Research Council (1977):

$\mathrm{GE}(\mathrm{kcal} / \mathrm{kg})=5^{\prime} 72(\%$ protein $)+9^{\prime} 50(\%$ lipids $)+4 ' 03(\%$ carbohydrates $)$

Stationary phases, corresponding to maximum biomass production, were compared by an overall multivariate one-way analysis of variance (ANOVA).

\section{RESULTS}

The marine microalga Dunaliella tertiolecta grew with the different nitrogen sources and in a wide range of $\mathrm{N}$ concentrations. Transmittance, expressed as (100 - T), was plotted against time and against nitrogen concentration for each source of nitrogen assayed (Fig. 1). Statistical treatment of these figures is presented in Table 1. Growth, expressed as 100 - $T$, tended to increase with the nitrogen concentration for each nitrogen compound used.

Considering the effect of the different nitrogen sources on the growth of $D$. tertiolecta for the same nitrogen concentration, growth on urea was significantly $(P<0.01)$ higher than growth in nitrite and nitrate at concentrations between 1 and $8 \mathrm{mg}$ atom. $\mathrm{N}$ /litre.

Optimal growth conditions for obtaining maximum cellular density in the stationary phase were $2 \mathrm{mg}$ atom. $\mathrm{N}$ /litre (Fig. 2), with cellular densities of $1.59 \times 10^{6}$ cells $/ \mathrm{ml}$ in nitrate cultures, $2.38 \times 10^{6} \mathrm{cells} / \mathrm{ml}$ in nitrite cultures and $2.97 \times 10^{6} \mathrm{cells} / \mathrm{ml}$ in urea cultures. At this optimum $\mathrm{N}$ concentration urea and nitrite cultures presented significantly higher cellular densities than nitrate $(P<0.01)$.

The source and concentration of nitrogen affected the protein content of $D$. tertiolecta cultures (Fig. 3). When the nitrogen concentration increased, the total protein content of the cultures and the protein per cell tended to increase. Maximum values of protein per $\mathrm{ml}$ of culture were found at higher nitrogen concentrations ( 8 and $16 \mathrm{mg}$ atom.N/litre), with values of $89.09 \mu \mathrm{g} / \mathrm{ml}$ in nitrate cultures, $76.62 \mu \mathrm{g} / \mathrm{ml}$ in nitrite cultures and $85-46 \mu \mathrm{g} / \mathrm{ml}$ in urea cultures. Although the protein content reached with the highest nitrogen concentration was very similar with the different nitrogen sources (Fig. 3(A)) the increase in the protein concentration with the $\mathrm{N}$ concentration was very different between urea cultures (organic nitrogen source) and nitrate and nitrite cultures 
(inorganic nitrogen sources). In urea cultures protein $/ \mathrm{ml}$ increased between 0.25 and 2 $\mathrm{mg}$ atom. $\mathrm{N}$ /litre, whereas in nitrate and nitrite cultures protein/ $\mathrm{ml}$ increased especially between 2 and $16 \mathrm{mg}$ atom.N/litre.

There was a marked increase in the protein/cell content with theinorganic sources of nitrogen for $\mathrm{N}$ concentrations above $2 \mathrm{mg}$ atom. $\mathrm{N} /$ litre, whereas little variations appeared in the urea cultures with the different nitrogen concentrations (Fig. 3(B)). Maximum protein/cell concentrations occurred at the higher nitrogen concentrations (8 and $16 \mathrm{mg}$ atom.N/litre) for all the $\mathrm{N}$ sources (Fig. 3(B)), with values of $103.59 \mathrm{pg} / \mathrm{cell}$ in nitrate cultures, $75.11 \mathrm{pg} / \mathrm{cell}$ in nitrite cultures and $33.51 \mathrm{pg} / \mathrm{cell}$ in urea cultures.

The efficiencies of nitrate-N/protein- $\mathrm{N}$, nitrite-N/protein- $\mathrm{N}$ and ureaN/protein- $\mathrm{N}$ transformation were calculated as the ratio between nitrogen added to the culture medium and the protein nitrogen produced per culture. Conversion was more efficient at low nitrogen concentrations for the three nitrogen compounds assayed (Fig. 4) with a highest value of $98.83 \%$ for the nitrate cultures at $0.25 \mathrm{mg}$ atom.N/litre. Efficiency decreased as nitrogen increased for all the nitrogen compounds, but in nitrate and nitrite cultures these decreases were more acute than in urea cultures and efficiency decreased to $50 \%$ when $\mathrm{N}$ concentration was doubled from 0.25 to $0.5 \mathrm{mg}$ atom.N/litre. The decrease in efficiency values was less in urea cultures.

The source and concentration of nitrogen affected the carbohydrate content per cell and per $\mathrm{ml}$ of culture of $\mathrm{D}$. tertiolecta cultures (Fig. 5). When the nitrogen concentration increased, the total carbohydrate content of the cultures increased proportionally to nitrogen concentrations. Maximum values of carbohydrate/ml were $25.50 \mu \mathrm{g} / \mathrm{ml}$ in nitrate cultures, $25.07 \mu \mathrm{g} / \mathrm{ml}$ in nitrite cultures and $30-40 \mu \mathrm{g} / \mathrm{ml}$ in urea cultures, at the higher nitrogen concentrations (8 and $16 \mathrm{mg}$ atom .N/litre) (Fig. 5(A)). Carbohydrate/cell ratio also increased with the $\mathrm{N}$ concentration, with maximum values at $16 \mathrm{mg}$ atom. $\mathrm{N} /$ litre for the three nitrogen sources used. These maximum values were $34.02 \mathrm{pg} / \mathrm{cell}$ in the nitrate cultures, $24-44 \mathrm{pg} / \mathrm{cell}$ in the nitrite cultures and 11.92 $\mathrm{pg} / \mathrm{cell}$ in the urea cultures.

Lipid concentrations per $\mathrm{ml}$ of culture appeared very similar between nitrate and nitrite cultures and with the different $\mathrm{N}$ concentrations, whereas in urea cultures there was a strong increase in the lipid $/ \mathrm{ml}$ concentration for $\mathrm{N}$ concentrations between 0.25 and 4 $\mathrm{mg}$ atom. $\mathrm{N} /$ litre, decreasing with higher $\mathrm{N}$ values (Fig. 6). Values were between 20.63 and $27.10 \mu \mathrm{g} / \mathrm{ml}$ in nitrate cultures, between 21.12 and $27.83 \mu \mathrm{g} / \mathrm{ml}$ in nitrite cultures and between 13.74 and $48-47 \mu \mathrm{g} / \mathrm{m} /$ in urea cultures. Lipid concentration per cell was 
less affected by the $\mathrm{N}$ concentration and values were very similar for the different $\mathrm{N}$ concentrations and sources. Chlorophyll a content per $\mathrm{ml}$ increased with the $\mathrm{N}$ concentration to 2-4 mg atom. $\mathrm{N} /$ litre, but with higher $\mathrm{N}$ values chlorophyll $\mathrm{a} / \mathrm{m} /$ content decreased (Fig. 7). Maximum values of chlorophyll $\mathrm{a} / \mathrm{m} /$ were obtained in urea cultures, followed by nitrite and nitrate cultures. Chlorophyll a/ cell ratios, contrarily, did not show a clear relation with $\mathrm{N}$ concentration and values were very similar for the different $\mathrm{N}$ sources, especially at $\mathrm{N}$ values higher than $2 \mathrm{mg}$ atom. $\mathrm{N} / \mathrm{litre}$. Maximum values of chlorophyll a/ $\mathrm{ml}$ were $5.53 \mu \mathrm{g} / \mathrm{ml}$ in nitrate cultures, $7.66 \mu \mathrm{g} / \mathrm{ml}$ in nitrite cultures and $12.10 \mu \mathrm{g} / \mathrm{ml}$ in urea cultures. Maximum concentrations of chlorophyll a per cell were $5.07 \mathrm{pg} / \mathrm{cell}$ in nitrate cultures, $3.66 \mathrm{pg} / \mathrm{cell}$ in nitrite cultures and 3-57 pg/cell in urea cultures.
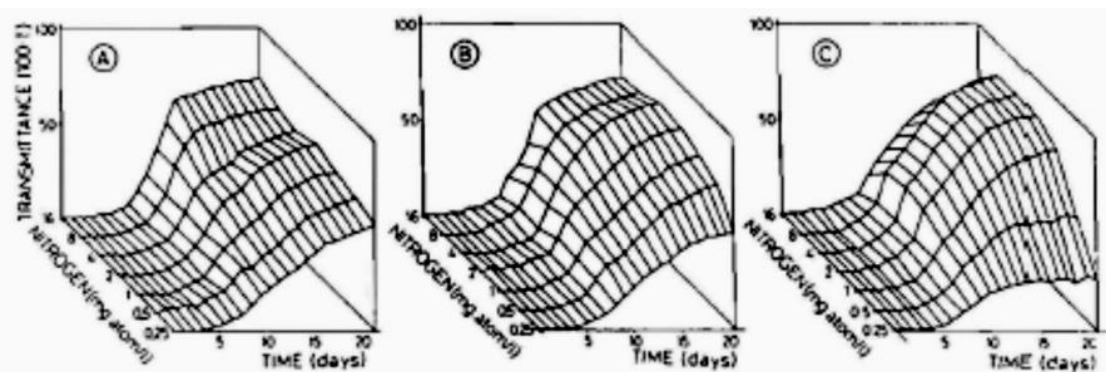

Fig. 1. Growth of $D$. tertiolecia with different sources and concentrations of nitrogen. Transmittance at $530 \mathrm{~nm}$ is expressed as $(100-T)$ values. (A)Cultures with nitrate; (B) nitrite and $(\mathrm{C})$ urea.

TABLE 1

Statistical Analysis of the Growth Curves of D. tertiolecta (Represented as $100-T$ ) at Different Salinities and Nutrient Concentrations

\begin{tabular}{|c|c|c|c|}
\hline & \multicolumn{3}{|c|}{ Nitrogen source } \\
\hline & Nitrate & Nitrile & Urea \\
\hline $0 \cdot 25$ & $\begin{array}{c}48 \cdot 50 \pm 3 \cdot 27 \\
=\end{array}$ & $\begin{array}{c}47 \cdot 25 \pm 2 \cdot 32 \\
<\end{array}$ & $\underset{<}{25 \cdot 25 \pm 2 \cdot 65}$ \\
\hline 0.50 & $\begin{array}{c}53 \cdot 67 \pm 4 \cdot 18 \\
=\end{array}$ & $\begin{array}{c}59 \cdot 83 \pm 4 \cdot 51 \\
-\end{array}$ & $\begin{array}{c}46.57 \pm 1.99 \\
<\end{array}$ \\
\hline 1 & $\begin{array}{c}59 \cdot 33 \pm 4 \cdot 08 \\
=\end{array}$ & $\begin{array}{c}64 \cdot 42 \pm 4 \cdot 72 \\
=\end{array}$ & $\begin{array}{c}70 \cdot 25 \pm 3 \cdot 63 \\
<\end{array}$ \\
\hline 2 & $\begin{array}{c}62 \cdot 57 \pm 4 \cdot 89 \\
-\end{array}$ & $\begin{array}{c}70 \cdot 75 \pm 4 \cdot 26 \\
=\end{array}$ & $\begin{array}{c}79 \cdot 08 \pm 4 \cdot 02 \\
=\end{array}$ \\
\hline 4 & $\begin{array}{c}59 \cdot 00 \pm 4 \cdot 30 \\
=\end{array}$ & $\begin{array}{c}75-08 \pm 3.79 \\
=\end{array}$ & $\begin{array}{c}81 \cdot 00 \pm 2 \cdot 74 \\
=\end{array}$ \\
\hline 8 & $\begin{array}{c}62 \cdot 44 \pm 4 \cdot 22 \\
<\end{array}$ & $\begin{array}{c}70-92 \pm 3 \cdot 25 \\
=\end{array}$ & $\begin{array}{c}80 \cdot 33 \pm 3 \cdot 60 \\
>\end{array}$ \\
\hline 16 & $69 \cdot 17 \pm 3 \cdot 29$ & $69 \cdot 00 \pm 3 \cdot 00$ & $67 \cdot 00 \pm 4 \cdot 55$ \\
\hline
\end{tabular}

Values are expressed as mean \pm standard deviation. Each value corresponding to a nitrogen concentration is compared by a one-way analysis of variance (ANOVA) with the following nitrogen concentrations. 


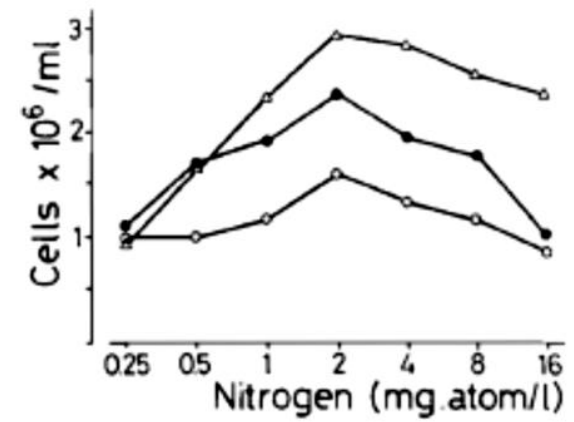

Fig. 2. Maximum cellular density of $D$. tertiolecta in the stationary phase at different sources and concentrations of nitrogen. $(0)$ Nitrate; $(\bullet)$ nitrite and $(\Delta)$ urea.
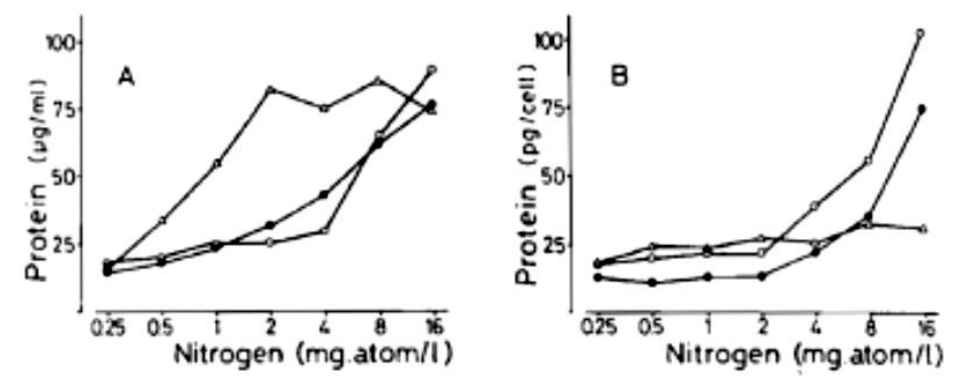

Fig. 3. Protein concentration in stationary phase of $D$. tertiolecta at different sources and concentrations of nitrogen. (A) Protein per $\mathrm{ml}(\mu \mathrm{g} / \mathrm{ml}) ;(B)$ protein per cell (pg/cell). $(0)$ Nitrate; $(\bullet)$ nitrite and $(\Delta)$ urea.

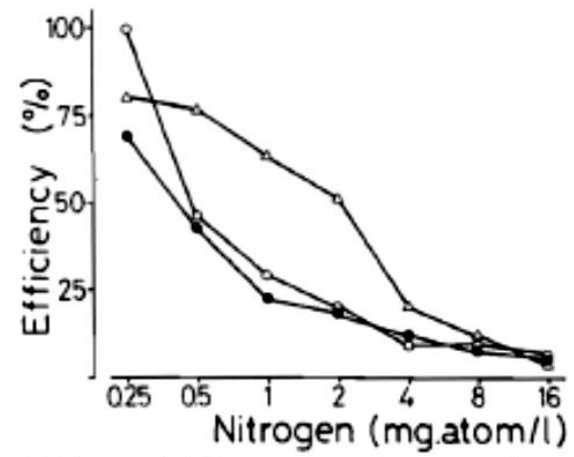

Fig. 4. Efficiency of $\mathrm{N} /$ protein- $\mathrm{N}$ transformation rate in stationary phase of $D$ tertiolecta at different sources and concentrations of nitrogen. $(0)$ Nitrate; $(\bullet)$ nitrite and $(\Delta)$ urea.
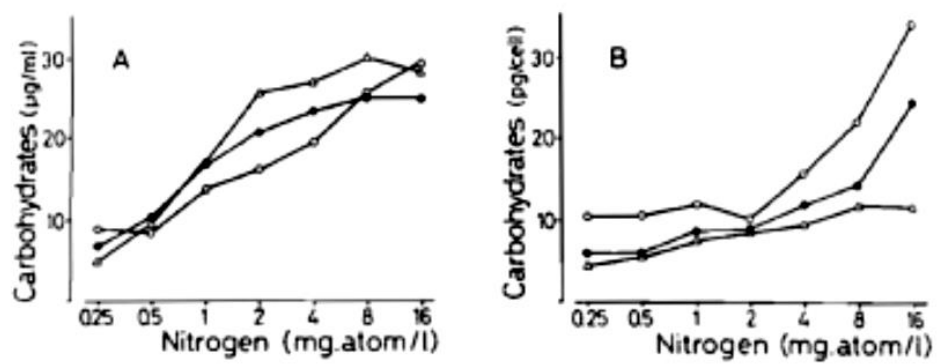

Fig. 5. Carbohydrate concentration in stationary phase of $D$. tertiolecta at different source and concentrations of nitrogen. (A) Carbohydrate per $\mathrm{ml}(\mu \mathrm{g} / \mathrm{ml}) ;(B)$ carbohydrate per cell $(\mathrm{pg} /$ cell). (O) Nitrate; $(\bullet)$ nitrite and $(\Delta)$ urea. 

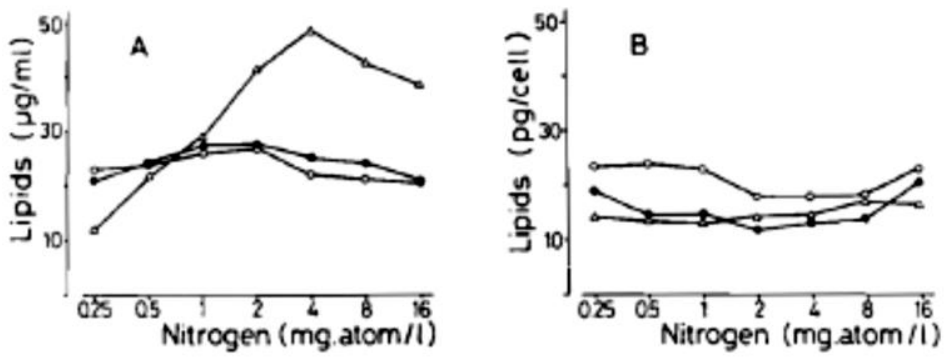

Fig. 6. Lipids concentration in stationary phase of $D$. tertiolecta at different sources and concentrations of nitrogen. (A) Lipids per $\mathrm{ml}(\mu \mathrm{g} / \mathrm{ml})$; (B) lipids per cell $\{\mathrm{pg} / \mathrm{cell}\}$. (O) Nitrate; $(\bullet)$ nitrite and $(\Delta)$ urea.

Protein/lipid ratio varied between 0.78 and 4.31 in nitrate cultures, between 0.72 and 3.62 in nitrite cultures and between 1.27 and 1.92 in urea cultures (Fig. 8(A)). Protein/lipid ratio increased proportionally to the increase of $\mathrm{N}$ amount in the culture medium in nitrate and nitrite cultures. Nitrate and nitrite cultures presented similar patterns in protein/lipid ratios with the different nitrogen concentrations. This ratio can be an indicator of $\mathrm{N}$ concentration in the culture medium when inorganic nitrogen is used, under the present conditions. In urea cultures, this ratio was constant with the different $\mathrm{N}$ concentrations.

Protein/carbohydrates ratio ranges between 1.74 and 3.04 in nitrate cultures, between 1.48 and 3.07 in nitrite cultures and between 2.64 and 4.14 in urea cultures (Fig. 8(B)). This ratio tended to increase with the $\mathrm{N}$ concentration in nitrate and nitrite cultures, whereas in urea cultures the protein/carbohydrates ratio tended to decrease with $\mathrm{N}$ concentration.

Lipid/carbohydrates ratio varied between 0.70 and 2.28 in nitrate cultures, between 0.84 and 3.05 in nitrite cultures and between 1.37 and 2.90 in urea cultures (Fig. 8(C)). Maximum values for this ratio occurred at the lower $\mathrm{N}$ concentrations. Lipid/carbohydrates ratio decreased proportionally to the increase of $\mathrm{N}$ amount in the culture medium. This decrease occurred with the three $\mathrm{N}$ sources assayed, nitrate, nitrite and urea. Lipid/carbohydrates relationship can be the best indicator of the $N$ availability in the culture medium. This relationship presented values between 0.7 and 3 in the cultures with the three $\mathrm{N}$ sources assayed.

Energy measurements were made on the basis of the composition in proteins, carbohydrates and lipids, calculating the gross energy of the microalga per litre of culture. Energy increased proportionally to the $\mathrm{N}$ concentration, except for urea cultures (Fig. 9). In these cultures energy increased quickly up to $2 \mathrm{mg}$ atom. $\mathrm{N}$ /litre and remained constant with higher $\mathrm{N}$ concentrations. Urea cultures presented the 
highest values of gross energy. Values were between 34.1 and $71.3 \mathrm{cal} /$ litre in nitrate cultures, between 29.6 and $64.5 \mathrm{cal} /$ litre in nitrite cultures and between 22.8 and 92.8 $\mathrm{cal} /$ itre in urea cultures.
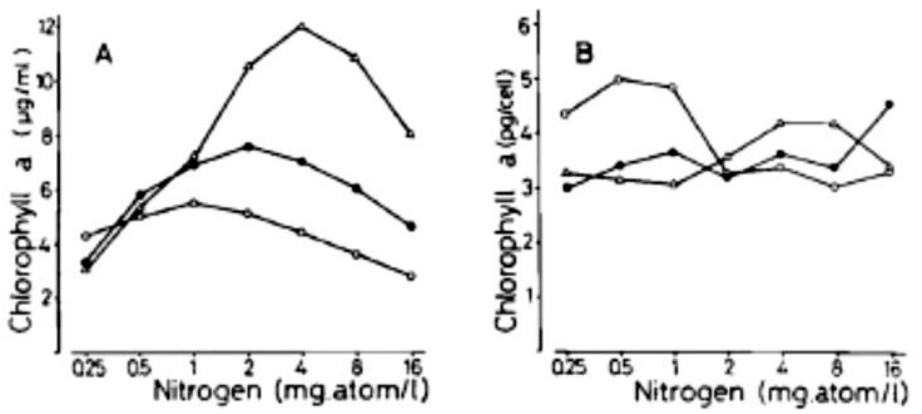

Fig. 7. Chlorophyll $a$ concentration in stationary phase of $D$. tertiolecta at different sources and concentrations of nitrogen. (A) Chlorophyll $a$ per $\mathrm{ml}(\mu \mathrm{g} / \mathrm{ml}) ;(B)$ chlorophyll $a$ per cell (pg/cell). (O) Nitrate; $(\bullet)$ nitrite and $(\Delta)$ urea.

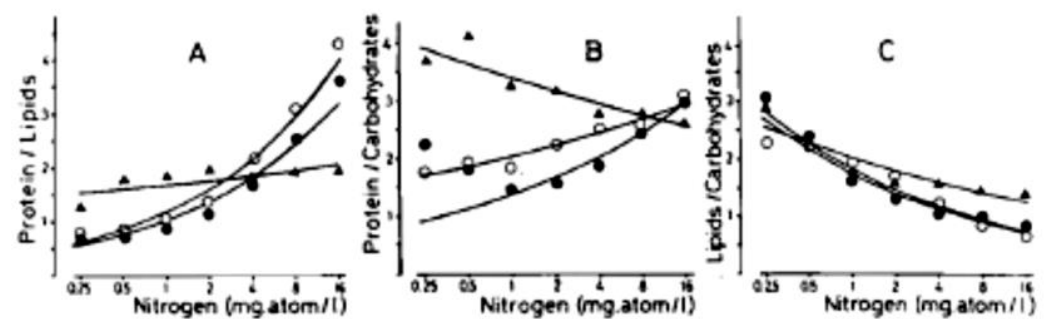

Fig. 8. (A) Protein/lipids, (B) protein/carbohydrates and (C) lipids/carbohydrates ratios against $\mathrm{N}$ concentration in stationary phase of $D$. tertiolecta at different sources and concentrations of nitrogen. $(0)$ Nitrate; $(\bullet)$ nitrite and $(\boldsymbol{\Delta})$ urea. These data fit to exponential curves with a general equation $y=a \cdot e^{\mathrm{bs}}$ and correlation coefficients of: (A) - nitrate, 0.96; nitrite, 0.95; urea, 0.47. (B) - nitrate, 0.95; nitrite, 0.96 ; urea, 0.84 . (C) - nitrate, $0 \cdot 93$; nitrite, $0-97$; urea, 0.87 .

\section{DISCUSSION}

We used exponentially nitrate growing D. tertiolecta cells as inoculum, without preadaptation for each nitrogen source. In general, little or no adaptation time is required for most of the marine microalgae in the $\mathrm{N}$ sources used in our experiments, beginning the exponential growth in the new sources after lag phases similar to those showed in the original $\mathrm{N}$ source (nitrate) as can be seen in Fig. 1. Adaptation before exponential growth is required for other $\mathrm{N}$ sources such as certain amino-acids (Landymore \& Antia, 1977).

The N/P ratio was maintained constant in order to produce the minimum changes as possible in parameters other than the source and concentration of $\mathrm{N}$ that affect to the biochemical composition of microalgal cells. It has been shown that the change of optimum N/P ratios in three microalgal species appears to be related to changes in cell 
protein contents (Wynne \& Rhee, 1986) and also affect the biochemical composition of D. tertiolecta (Wikfors, 1986).

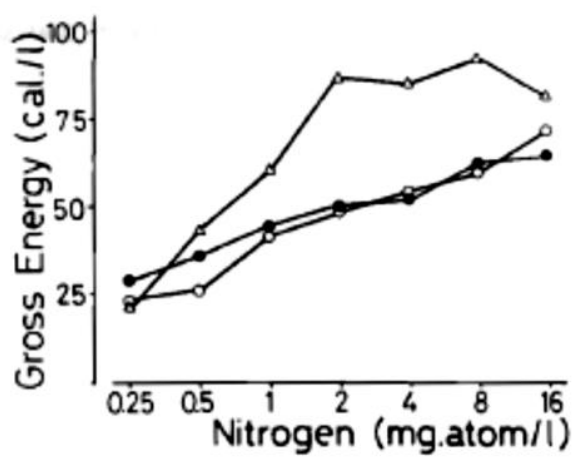

Fig. 9. Gross energy (cal/litre) in stationary phase of $D$. tertiolecta culture at different sources and concentrations of nitrogen. $(0)$ Nitrate; $(\bullet)$ nitrite and $(\Delta)$ urea.

The kinetics of the cultures were followed from transmittance (100 - T) measurements. The growth of microalgae in batch cultures is often well characterized by the logistic growth function (Schantz \& Zahler, 1981). In the stationary phase and under certain conditions, transmittance measurements can be transformed into cellular densities (Lyon \& Woo, 1980), and the relationship between optical density and cellular density fits to a linear equation in D. tertiolecta (Fabregas et al., 1986b). In the cultures of D. tertiolecta with the different nitrogen sources there is not a direct relationship between cellular density and optical density (Fig. 1).

The $\mathrm{N}$ concentration range used had no significant effect on the velocity of growth of $\mathrm{D}$. tertiolecta cultures in comparison with their effect on biomass production reached in the stationary phase. The biomass production at the end of the stationary phase, expressed as cellular density (Fig. 2), was affected by both the source and concentration of nitrogen used. Velocity of growth in the logarithmic phase was practically constant under all the conditions, with $0.34 \pm 0.09$ doublings/day. As previously shown, variations in salinity and in nutrient concentration had a greater effect on the final biomass of Dunaliella tertiolecta than on the velocity of growth (Fabregas et al., 1986b ).

Cellular density increases proportionally to the increase of the $\mathrm{N}$ concentration in the culture medium from 0.25 to $2 \mathrm{mg}$ atom. $\mathrm{N}$ /litre. Maximum cellular density was obtained with a concentration of $2 \mathrm{mg}$ atom. $\mathrm{N}$ /litre for all the $\mathrm{N}$ sources used. These results are in general accordance with those obtained with six marine microalgae grown at different concentrations of nutrients. The absolute maximum biomass was 
obtained at approximately $1700 \mu \mathrm{g}$ atom . N/litre and other nutrients at balanced levels with laboratory-grade compounds (Maestrini \& Gonzalez-Rodriguez, 1983).

Cellular density decreases at higher $\mathrm{N}$ concentrations. This decrease suggests a variation in the cellular volume, cellular composition or toxicity of $\mathrm{N}$ sources. Toxic effects of nitrate and urea at high concentrations are not known. Nitrite can serve as a $\mathrm{N}$ source for many species of marine microalgae only at low concentrations, about 1 $\mathrm{mg}$ atom. $\mathrm{N}$ /litre, but at higher concentrations nitrite inhibits the microalgal growth (Kaplan et al., 1986). However, different species of benthic diatoms grew well in media with high concentrations of nitrite ion $(1.10 \mathrm{mg}$ atom. $\mathrm{N} /$ litre) and inhibition was not produced (Admirall, 1977).

Conversion of $\mathrm{N}$ added to culture medium into protein- $\mathrm{N}$ was, generally, more efficient in urea cultures (Fig. 4). This fact can be due to the organic nature of the urea molecule which contains carbon. Urea generally is hydrolysed by urease or UALase (urea amidolyase) activity (Bekheit \& Syrett, 1977); this hydrolysis rendered two moles of ammonium and one of $\mathrm{CO}_{2}$, The higher cellular density reached in urea cultures is probably due to this molecule of $\mathrm{CO}_{2}$ from urea metabolism, and this also improved the urea-N/protein- $\mathrm{N}$ efficiency. The lowest concentrations of the three $\mathrm{N}$ sources lead to the best use of nitrogen by this microalga, with a minimum waste, under the present conditions.

Protein/cell content is affected by the different concentrations of nitrate and nitrite (Fig. 3). Physiological events associated with nutrient concentrations are reflected in protein/cell content. The highest concentrations of protein in D. tertiolecta occur with the higher nitrogen concentrations, increasing with the increase in $\mathrm{N}$ concentration.

Taking into account that maximum cellular density occurs at $2 \mathrm{mg}$ atom. $\mathrm{N} /$ /itre for all the $\mathrm{N}$ sources used and that biochemical variability in microalgal cells drastically occurs at concentrations higher than 2 tng atom. $\mathrm{K}$ /litre, it is possible to define the microalgal cultures with different nitrogen sources as:

1. Cultures at low nitrogen concentration, for $\mathrm{N}$ values less than $2 \mathrm{mg}$ atom. $\mathrm{N} /$ /itre.

2. Cultures at high nitrogen concentration, for $\mathrm{N}$ values higher than $2 \mathrm{mg}$ atom. $\mathrm{N}$ /litre.

In the first group established above, the protein/cell content and carbohydrates/cell content remain constant (Figs 3,5 ) whereas the cellular density increases proportionally to the $\mathrm{N}$ concentration. In the second group established above (high $\mathrm{N}$ 
concentration) chemical variability is shown, and protein/cell and carbohydrates/cell content increase proportionally to the $N$ increase up to $16 \mathrm{mg}$ atom. $N /$ itre (Figs $3(B)$, 5(B)), whereas the cellular density tended to decrease (Fig. 2). Lipid content, however, did not show this pattern of chemical variability (Fig. 6).

Maximum protein/cell values occurred at the highest nitrogen concentrations (16 $\mathrm{mg}$ atom. $\mathrm{N}$ /litre) and comparing all $\mathrm{N}$ sources maximum protein/cell concentrations were obtained in the cultures with nitrate. Protein/cell values of up to 4.94, 5.47 and 1.41 times higher have been observed in nitrate, nitrite and urea cultures, respectively, when comparing protein/cell values obtained in high $\mathrm{N}$ cultures with those obtained in low $\mathrm{N}$ cultures. Similar variation in the chemical composition has been observed in other microalgae but at low nutrient concentrations. The chemical composition of cells of Chaetoceros affinis var. willei (Gran) Hustedt grown in batch culture was markedly influenced by the concentration of nutrients in the medium at low nutrient concentrations, using dilutions of " $f$ " medium from $f / 2$ to $f / 50$. The nitrogen concentration in these $f$ dilutions ranged from 0.03 to $0.88 \mathrm{mg}$ atom. $\mathrm{N} /$ litre. The protein content varied from $49 \%$ in the medium with the highest concentration of nutrients (f/2) to $12.5 \%$ at the lowest concentration ( $f / 50)$ (Myklestad \& Haug, 1972).

Biochemical variability was also observed in the carbohydrates/cell content for high $\mathrm{N}$ concentrations (> $2 \mathrm{mg}$ atom. $\mathrm{N}$ /litre). Values of $3.16,3.30$ and 1.77 times higher have been observed in the nitrate, nitrite and urea cultures, respectively, comparing carbohydrate values in cultures at high $\mathrm{N}$ concentrations with those obtained at low $\mathrm{N}$ concentrations for each $\mathrm{N}$ source.

Chlorophyll content did not show cellular variability and it is closely related to the cellular density (Fig. 7).

Lipid concentrations did not show variations as proteins and carbohydrates and they remain constant both at low and at high $\mathrm{N}$ concentrations (Fig. 6), although variations in lipid content are very pronounced if they are expressed as relative percentages to protein and carbohydrates content. Lipids of D. tertiolecta constitute about $12 \%$ of the dry weight. Environmental factors can affect the total amount of lipids (Utting, 1985; Cohen, 1986). Total lipids fractions in microalgae vary substantially from less than $1 \%$ to more than $40 \%$ of dry weight (Paoletti, 1976; Dubinsky et al., 1978).

Protein/carbohydrate ratio is maintained within the range 1/4-4.2. This ratio increases with the $\mathrm{N}$ concentration in nitrate and nitrite cultures, whereas it decreases in urea cultures under the same conditions, probably due to the presence of carbon in the urea 
molecule which acts on the carbohydrate fraction. Protein/carbohydrate ratio seems to be a convenient parameter for characterizing the physiological state of a microalgal cell (Myklestad \& Haug, 1972) and the nutrient deficiency (Ganf et al., 1986). A general relationship existed between growth rate and the protein to carbohydrate ratio for ratios 2 ; below this value, however, growth rate was independent of the protein to carbohydrate ratio (Ganf et al., 1986). However, although protein/carbohydrate ratio can be a convenient parameter for characterizing the physiological state of a microalgal cell, lipid/carbohydrate ratio can be more suitable, because linear relationships between this ratio and $\mathrm{N}$ concentration are more similar among the three $\mathrm{N}$ sources than linear relationships for protein/carbohydrate. This lipid/carbohydrate ratio seems to be the best ratio for reflecting the physiological state of micro algae grown in different $\mathrm{N}$ sources and concentrations (Fig. 8).

Energy measurements of organic compounds were carried out on the basis of dry weight, knowing the composition in protein, carbohydrate and lipid. These kinds of measurements are also used for microalgae. But if we take into account that these micro-organisms are used in feeding molluscs, larvae, etc., suspended in liquid medium at a known density, we can calculate the energy of microalgae per $\mathrm{ml}$ of culture.

Gross energy values show differences of 109,117 and $255 \%$ in nitrate, nitrite and urea cultures, respectively. It has been reported that Tetraselmis had 34\% more energy available when grown in normal compared to nitrogen-deficient medium in nitrate cultures (Utting, 1985). Energy increases proportionally to the $\mathrm{N}$ concentration both at low and high $\mathrm{N}$ cultures in nitrate and nitrite cultures, whereas in urea cultures energy increases with $\mathrm{N}$ concentration in low $\mathrm{N}$ cultures and is practically constant in high $\mathrm{N}$ urea cultures.

Biochemical variability of the marine microalga Dunaliella tertiolecta at different sources and concentrations of nitrogen can change their nutritive value, with a potential effect on their value as single cell protein (Fabregas \& Herrero, 1985), chemicals (Ben-Amotz \& Avron, 1980; Evans et al., 1982; Borowitzka, 1986) or as feed in mariculture (Fabregas \& Herrero, 1986; Scott \& Baynes, 1979; Wikfors et al. , 1984). In mariculture it has been already proved that differences in growth media affect the gross chemical composition of algal food sources which alone can account for differences in algal nutritional value to C. virginica (Wikfors et al., 1984). 
An improved knowledge of the growth, composition and chemical variability of a species such as $D$. tertiolecta, and its possible manipulation, varying only the source and concentration of $\mathrm{N}$, will enable its better use and obtain high algal yields.

\section{ACKNOWLEDGEMENTS}

This work has been supported by a grant from Conselleria de Educación, Xunta de Galicia (D.O.G. 16-12-87).

\section{REFERENCES}

Admiraal W. Tolerance of estuarine benthic diatoms to high concentrations of ammonia, nitrite ion, nitrate ion and orthophosphate. Mar Biol 1977;43(4):307-15.

Bekheet IA, Syrett PJ. Urea-degrading enzymes in algae. Br.Phycol.J. 1977;12(2):137-43.

Ben-Amotz A, Avron M. On the mechanism of osmoregulation in dunaliella. Energetics and Structure of Halophilic Microorganisms 1978:529-41.

Ben-Amotz A, Avron M. Glycerol, $\beta$-carotene and dry algal meal production by commercial cultivation of dunaliella. Algae Biomass 1980:603-10.

Borowitzka MA. Micro-algae as sources of fine chemicals. Microbiol Sci 1986;3(12):372-5.

Bradford MM. A rapid and sensitive method for the quantitation of microgram quantities of protein utilizing the principle of protein-dye binding. Anal Biochem 1976;72(1-2):248-54 .

Cohen Z. Products from microalgae. Handbook of Microalgal Mass Culture 1986:421-54.

Dubinsky Z, Berner T, Aaronson S. Potential of large-scale algal culture for biomass and lipid production in arid lands. Biotechnol Bioeng Symp 1979;Symp. No.8:51-68.

Evans RW, Kates M, Ginzburg M, Ginzburg B-. Lipid composition of halotolerant algae, dunaliella parva lerche and dunaliella tertiolecta. Biochim Biophys Acta Lipids Lipid Metab 1982;712(1):186-95.

Fabregas J, Herrero C. Marine microalgae as a potential source of single cell protein (SCP). Appl Microbiol Biotechnol 1985;23(2):110-3.

Fabregas J, Herrero C. Marine microalgae as a potential source of minerals in fish diets. Aquaculture 1986;51(3-4):237-43.

Fabregas J, Herrero C, Veiga M. Effect of oil and dispersant on growth and chlorophyll a content of the marine microalga tetraselmis suecica. Appl Environ Microbiol 1984;47(2):445-7. 
Fabregas J, Herrero C, Cabezas B, Abalde J. Mass culture and biochemical variability of the marine microalga tetraselmis suecica kylin (butch) with high nutrient concentrations. Aquaculture 1985;49(3-4):231-44.

Fabregas J, Herrero C, Abalde J, Liaño R, Cabezas B. Biomass production and biochemical variability of the marine microalga dunaliella tertiolecta (butcher) with high nutrient concentrations. Aquaculture 1986;53(3-4):187-99.

Fabregas J, Herrero C, Cabezas B, Liaño R, Abalde J. Response of the marine microalga dunaliella tertiolecta to nutrient concentration and salinity variations in batch cultures. $J$ Plant Physiol 1986;125(5):475-84.

Ganf GG, Stone SJL, Oliver RL. Use of protein to carbohydrate ratios to analyse for nutrient deficiency in phytoplankton. Australian Journal of Marine \& Freshwater Research 1986;37(2):183-97.

Hobson LA, Pariser RJ. The effect of inorganic nitrogen on macromolecular synthesis by thalassiosira fluviatilis hustedt and cyclotella nana hustedt grown in batch culture. J Exp Mar Biol Ecol 1971;6(1):71-8.

Kaplan D, Richmond AE, Dubinsky Z, Aaronson S. Algal nutrition. Handbook of Microalgal Mass Culture 1986:147-98.

Kochert G. Carbohydrate determination by the phenol-sulfuric acid method. Handbook of Phycological Methods.Physiological and Biochemical Methods 1978:95-7.

Kochert G. Quantitation of the macromolecular components of microalgae. Handbook of Phycological Methods.Physiological and Biochemical Methods 1978:189-95.

Landymore AF, Antia NJ. Growth of a marine diatom and a haptophycean alga on phenylalanine or tyrosine as sole nitrogen source. J Phycol 1977;13:231-8.

Lyon HW, Woo CS. Accelerated uptake response of the green alga, chlorella vulgaris, to high levels of phosphorus in mississippi river water. Sci Total Environ 1980;14(3):279-85.

Maestrini S, Gonzalez-Rodriguez E. Relative yields of marine algae grown in heavily nutrientenriched seawater. La Mer 1983;21:145-50.

Marsh JB, Weinstein DB. Simple charring method for determination of lipids. J Lipid Res 1966;7(4):574-6.

Mason DT. The growth response of artemia salina (L.) to various feeding regimes. Crustaceana 1963;5(2):138-50. 
Myklestad S, Haug A. Production of carbohydrates by the marine diatom chaetoceros affinis var. willei (gran) hustedt. I. effect of the concentration of nutrients in the culture medium. J Exp Mar Biol Ecol 1972;9(2):125-36.

National Research Council. Nutrient Requirements of Coldwater Fishes 1981.

Oliveira L, Bisalputra T, Antia NJ. Ultrastructural observation of the surface coat of dunaliella tertiolecta from staining with cationic dyes and enzyme treatments. New Phytol 1980;85:385-92.

Paoletti C, Pushparaj B, Florenzano G, Capella P, Lercker G. Unsaponifiable matter of green and blue-green algal lipids as a factor of biochemical differentiation of their biomasses: I. total unsaponifiable and hydrocarbon fraction. Lipids 1976;11(4):258-65.

Parsons TR, Strickland JDH. Particulate organic matter. III.I. pigment analysis. III.I.I. determination of phytoplankton pigments. J.Fish.Res.Board can. 1965;18:117-27.

Schanz F, Zahler U. Prediction of algal growth in batch cultures. Schweiz Z Hydrologie 1981;43(1):103-13.

Scott A, Baynes S. The effect of unicellular algae on survival and growth of turbot larvae (scophthalmus maximus L.). Finfish Nutrition and Fishfeed Technology 1979;1:423-33.

Spoehr HA, Milner HW. The chemical composition of chlorella; effect of environmental conditions. Plant Physiol 1949;24(1):120-49.

Utting SD. Influence of nitrogen availability on the biochemical composition of three unicellular marine algae of commercial importance. Aquac Eng 1985;4(3):175-90.

Walne PR. Culture of Bivalve Molluscs 1974.

Wynne D, Rhee G. Effects of light intensity and quality on the relative $\mathrm{N}$ and $\mathrm{P}$ requirement (the optimum N:P ratio) of marine planktonic algae. J Plankton Res 1986;8(1):91-103.

Wikfors GH. Altering growth and gross chemical composition of two microalgal molluscan food species by varying nitrate and phosphate. Aquaculture 1986;59(1):1-14.

Wikfors GH, Twarog JW, Ukeles R. Influence of chemical composition of algal food sources on growth of juvenile oysters, crassostrea virginica. Biol Bull 1984;167:251-63. 